\title{
Evaluation of the Relevant Factors with the Formation of Marginalization in Qorveh, a Case Study in Sheikh Jafar Quarter
}

\author{
Ata Olah Erfani ${ }^{1}$, Masoud Almasi' ${ }^{2}$, Hamideh Reshadatjoo ${ }^{3}$ \\ ${ }^{1}$ M.A of Urban Management, Islamic Azad University, Science and Research, Tehran Branch, \\ Iran \\ ${ }^{2}$ Faculty Member of Political Geography, Islamic Azad University, Qeshm Branch, Iran \\ ${ }^{3}$ Faculty Member of Higher education management, Islamic Azad University, Science and \\ Research, Tehran Branch, Iran
}

Received: 24 October 2018, Revised: 05 December 2018, Accepted: 20 December 2018

\begin{abstract}
Marginalization as a challenge underhand of urban development areas, turns regions and its surrounding into problematic and vulnerable areas. This phenomenon is dramatically increasing in Qorveh. Considering the importance of Qorveh in terms of economic, cultural, social and strategic positions in Kurdistan, marginalized quarters around this city and their consequences have created some problems. This research seeks to explore the relevant factors with formation of marginalization in Sheikh Jafar Quarter of Qorveh city. This survey study was carried out among the population of marginalized residents of Sheikh Jafar quarter in Qorveh in 2013. Out of about 97 households, a sample containing 78 households was determined using Cochran formula by simple random sampling. Visiting the head of the household, we collected all the required information through a researcher-made questionnaire. This questionnaire categorizes the marginalization into three dimensions: 1 ) economic factors, 2) social factors, and 3) cultural factors. The validity of the questionnaire was approved by the experts. As for its reliability, its reliability coefficient for was 772/0, $732 / 0$ and 748/0 for the economic factors, social factors and cultural factors, respectively. The collected data were analyzed using indexes of descriptive statistics, one- sample t-test and Friedman test. The results of one-sample t-test showed that according to the respondents, the economic and cultural factors had a role in the marginalization whereas the social factors had no role in this process. Moreover, the Friedman test showed prioritization of the factors in the marginalization was respectively the economic, cultural and social factors. It is accordingly concluded that any planning and organization of the marginalized areas should be done based on the aforesaid factors.
\end{abstract}

Keywords: City, Marginalization, Economic Factor, Cultural factor and etc. 


\section{Introduction}

The marginalization results from consequences of uneven and irregular development in urban system. More than $60 \%$ of the world's population lives in cities. Many social, economic and political issues in developing countries originates in poor growth and development of systems and urban spaces. In urban development process, especially after land reforms in Iran, due to changes in by changing the social and economic traditional structure, unequal distribution of resources and facilities in regional spaces have been developed that have led to we were providing requirements of deformed structure formation by poor modern social status. Areas without facilities and urban services or with facilities and poor urban services were created (Zahed Zahedani, 1990, 25). When the macro-structure in unequal distribution of the capital deprives some regional spaces as villages and small cities, it creates some dependent systems, informal marginal, lagged, informal settlements and immigrants. Basically, marginalization is a kind of social and spatial chaos which challenges continually principles and strategies of sustainable development of the society. This phenomenon in social contexts is influenced by functional impairment in the social order and inequality in cultural, political, economic and social dimensions that generate poverty, inflation, migration, marginalization in depth and in surface, damages, deviations and social disturbances in open social security (Kargar and Sarvar, 2011, 107 and 108). According to statistics, in developing countries, $50 \%$ of urban population lives in slums and marginalized regions that in some cities this proportion increases by $80 \%$. By increase in urban development and population of predominant and large cities of Third World, slums and marginalized areas are rapidly increasing (Shokouei, 2000). Based on the studies in marginalization in different marginalized areas of big cities of Iran, its main features are as follows: overcrowd, poor construction, culture, society and economic poverty, unemployment, false employment, lack of public hygiene, lack of educational and welfare facilities, crime, criminality and corruption increase (Rabbani et al. 2009, 94). The increase in the population increase of Qorveh along with physical extension of the city has made service supply difficult and expensive and created issues such lack of green spaces and facilities in urban services, lack of educational space, lack of medical facilities and finally, pollution and traffic and ten more items. One of the settlements in margin area of Qorveh is a popular area named Sheikh Jafar located in the northern part of Qorveh along with Hamedan-Sanandaj suburban road which is the main factor limiting physical development of the city from north side. This area which has grown improperly continues its physical development.

Lack of employment and education facilities for youth in one hand and economic and cultural poverty ruling the area plus shortage of waste collecting system, sewage and waste of disposal costs have resulted in pollution in the area that in turn has led to problems for which there are no solutions due to poverty of area and lack of social supports. To solve this problem, the cause and circumstances of its formation need to be evaluated in depth and it should be rooted out by submission of a suitable solution. This research is an entry to evaluate factors related to marginalization formation in Sheikh Jafar Quarter in Qorveh. This study focused on 
roots and causes of such phenomenon by submitting appropriate solutions.

\section{Problem Statement}

A part of the defects in urban management stems from this fact that the phenomenon of the city is not understood and dealt with seriously and the city issue has been evaluated by technocratic vision. Since city is a social production and direction of the national development passes through urban development, as long as the city issue is not solved, the national development issue will not be solved either. Accordingly, a wide range of experts is required to work together to proceed such system (Sarvar 2011, 17).

Based on General Census of 2011, not only has fast urbanism increased, started in late 1961 in Iran, but also it has reached to a new top. The urban population of the country in 2006 reached 70495782 and rose to $75,149,669$ in 2011 while the rural population in 2006 reduced by $22,131,101$ people, with an average growth rate per year $(-40)$ percent, and in 2011 reduced by $21,446,783$ people with the average annual growth rate (63) percentage( Statistical Center of Iran, 2011). Rural depopulation means that the villagers have migrated to the cities during the last 5 years. And due to lack of proper planning and high prices of housing and lands in the city limits and economic, social, and cultural conditions, refugees are inevitably settled in city sanctums so that it will lead to creation of marginalization or informal settlements.

Qorveh is dealing with some issues and problems due to growth of migrants' population and the development of building complexes in a part of its regions and lack of construction permits in some areas which has resulted in dissatisfaction and passing informal paths and finally formation of marginalization in Qorveh sanctum. However, despite considerable attention paid to providing facilities to the villages of this province, we are still witnessing migration and high tendency of the villagers toward living in cities. It seems that this issue can be examined as below: 1- Breaking the power structure of rural life: human being used to transfer his mental and abstract issues to others through his surrounding phenomenon and he evaluated the society by his organism. The similarity of thought of society and organism leads to creation of the organism which has a long history behind. Plato considered the world as a body, and divided it to three sections: head (rulers and administrators of society), heart (army and military forces), and abdomen (those who provide people's requirement). According to the similarity of the body organism and the society, the social disorders and instability can be defined. Before revolution, people in the villages were responsible for choosing people such as plain guide (keeping the products against animals and other people), chief (in charge of social management of the village and was chosen by people and appointed by owner), water distributor (in charge of maintenance, repair of water resources and distribution), bathkeeper, barber, carpenter and etc. and they used to pay them. When Reza Khan came to power, in one hand, he tried to dismantle and damage organization's functionality and communities by using modern bureaucracy toward modernity which was in contrast to tradition and in other hand, he was unsuccessful in building modern democratic institutions. 
After Islamic Revolution, a type of local government was shaped in villages by formation of Islamic Councils which requires more support and greater public participation in order to be a regulatory factor for social relations, customs and public beliefs.

2- Comprehensive and pilot project are without suitable economic, social, and cultural attachments of village residents, resulting in designing and structural maps of villages which were conducted based on designing urban buildings. And in building maps of the villages, there was no attention to social-cultural issue of villagers and no attention paid to providing a place for livestock, barns and etc. on which the rural economy is dependent. It was not only effective in encouraging the villagers to settle in the rural areas, but also it was a factor per se to encourage migration to the cities, rural demands from urbanism and urban life. On the other hand, owing to the lack of financial and economic compliance and also poor urban management, which had no proper planning for such people, they settled inevitably on the edge of cities and created problems of marginalization.

3- In comprehensive projects of the city by identification of sanctum line and only defining it physically regarding construction ban in such places, we still witness violation of the sanctums and irregular non-normative constructions which lack building national guidelines and regulations. Further, they are mostly done by the low-incomes living in the cities. Therefore, the relevant organizations are forced to review urban and construction comprehensive projects and add them to the urban limits and define another spectrum line. A part of such problems stem from lack of urban management because the urban space consists of two parts: body (including physical factors as buildings, roads and lands) and content (including economic, social, cultural and political construction). Planning and lands separation should be done in accordance with the economic status of all society classes along with the main objective of the comprehensive projects which is organization of human, space and activities' rapports. On the other hand, economic, social and cultural attachments of human being should be considered and it seems that it will be effective in controlling marginalization and problems resulting from it. Therefore, in urban planning we require a comprehensive review instead of comprehensive urban project.

4- $\quad$ Sustainable employment creation in villages: the economy of the villages is based on subsistence economy (their subsistence depends on the environment). In the recent years, some remarkable measures have been made along with granting banking facilities and loans with low interest. However, perhaps due to lack of socially and culturally proper attachments in the studies, such measures have not been effective in stopping villagers from migrating. Therefore, the main problems and issues that this research intends to clarify is whether economic, social and cultural factors have effect on marginalization. And which of these factors matter more.

\section{The Importance and Necessity of Research}

In a society, there might appear two sections, one with more facilities as the result of allocating more economic and social facilities and the other section which is unprivileged and underdeveloped.

However, unrealistic adoption of developing countries from utopian regulation and criteria of urbanism in developed countries, in accordance with 
their economic status, is not high population growth and low-income of major part of the society. Therefore, due to deficiencies of housing planning, people who gain low incomes are not only deprived from the government funding, but also new economic institutions, namely banks, don't cover them. As a result, such social groups, hopeless of formal physical planning whose ideal criteria and regulations deprive them from citizenship rights, are driven toward an urban area which lacks stable regulations. Moreover, it is located as "informal Housing" of the cities' sanctum and are mostly named "marginalization". They are built illegally in order to force the service organizations to provide them with required services. Therefore, shortcomings of the physical planning which are regarded as an obstacle to provide lowincome people with urban and urbanization technics stop promoting knowledge of urbanization and granting the citizenship's rights to rural low-income migrants. Consequently, all service costs to the forgotten low-income areas will be hefty (Athari, 2000).

The city sanctum is so-called a place to breath and maintain; it is also a place of maintenance of the sanctum and city ecologic values, a place to recreate and having pastime, a place which is dedicate to specific applications which is better to be out of the town like huge hospitals, sport complexes or nursing home and tourism recreation places. Therefore, of the main responsibilities of the urban management, study and planning to prevent so-called automatic and informal settlement could be mentioned (Sarvar, 2011, 23).

In line with the mentioned description the population of Qorveh which was 199834 in 1996 rose to 222692 in 2004 (population changes in 2004 was $11 / 43 \%$ compared to 1996). Moreover, in 2010, of the total population of the province, 96792 formed population of Qorveh (Term Comprehensive Plan, 2011). Due to having suitable land, mountain, plain, livestock and agriculture, it was expected that marginalization in this city would not be shaped. However, the marginalization phenomenon is increasing in this city. It also affects the whole city which can lead to the emergence of various abnormalities in urbanism. Employment of people living in the marginalization in informal and false jobs, unauthorized constructions, lack of municipality's capability to provide proper services in such areas, environment population, undesirable cultural, economic, social and political effects in regions on total system of the city, crime increase and deviance, are all the consequences of destructive and malicious marginalization, either for residents of those areas or for residents of the city.

In Qorveh, the third quarter "Sheikh Jafar" in comparison with other marginalized quarters in terms of antiquity is one of the marginalized quarters of Qorveh. Studying and evaluation such quarters is the responsibility of authorities and practitioners of urban issues and researchscience centers because most of the urban problems in big cities result from the formation, engendering social injustice in the cities and social, cultural and economic consequences. Organization of Sheikh Jafar quarter in Qorveh is not only helping to improve appearance of the city, but also it leads to promote social-economic and cultural level locally and nationally.

\section{Background Studied in the World (Assumptions)}

Castelles (1977) in a research about marginalization groups in developing countries states that The urbanism is 
increasing with an accelerating rate while facilities of job creation for new-comers population (immigrants) are not provided, facilities such as infrastructure, social and physical facilities, settlements and unconventional quarters such as slums and marginal sheds which are built by new-comer and poor immigrants using automatic and auto-built method. In the end, he believes that marginalization is born by social-economic inequalities and uneven urbanization and transfer of village poverty to city poverty. Analyzing different policies in organization of informal settlements through study of informal settlements in Pune in India, Kapoor (1987) along with members of research team of World Bank Development, in a research named "Location and Welfare in Cities", while, proved that among various strategies such as displacement and resettlement (if leading to improve environmental situations in settlement), mitigation policies at the current location (in-place) are superior to other options. Nelson (1988) conducted a research on gendered division of labor in the informal automatic settlements in Nairobi. He showed that alcohol, illegal drugs and prostitutions had spread a shadow over women's job in this region. There are a few jobs in this area. House works made women capable of taking care of their children, divisions between formal and informal sector are unstable and variable based on the conditions. If the private sector provides people with enough job opportunities, the informal sector will lose its importance inevitably. However, if the formal sector does not provide people with job opportunities, the informal sector will be focused as an important strategy to meet desirable life for people. In research conducted by Elyas (1966), Marshal Clinard (1966), and more indirectly George Toli (1989) the social and economic factors in marginalization of cities and rural migrations have been pointed. A.M.Favio De Suza (2001) in the study of informal settlements of Recife city in Brazil considers security in residence as the main significant capital in improvement of the informal settlements' status and regards it as the major factor to strengthen (physical-functional) of unconventional dwellings.

Warren Smith, (2005) found in a that improvement of informal settlements should be always as an integral part of an integrated strategy of housing including and the offered options suit different residential needs, transparent allocation of resources and the frameworks of specified period of time.

The Integrated Housing Strategy requires a prudent policy in which people can have rapid access to land and basic infrastructures before creating new informal settlements.

\section{Background Studies in Iran}

The phenomenon of marginalization was dormant for ages in Iran and custodians and researchers were stunned to broad and remarkable development of cities over many years. Unrealistic Due to the increased share of oil development in the national economy and modernization by the pseudo- policy regime, the tendency to urbanization was intensified (Soltanzadeh, 1976).

But the unbridled development soon indicated its unwanted side effects, so in late 1972, serious concerns were raised. For this reason, several studies began at this time.

Of the most important research studies, the following can be mentioned: research of the Institute for Social Research and studies, Tehran University 
(1972), in relation to urban slum dwellers of Bushehr and review urban marginalization dwellers of sociology and Qaleh Golabi et al. (1971), Niroumand et al. (1974), Plan and Budget Organization of West Azarbaijan (PBO)(1974), Khonsari (1976), Zahid Zahedani (1975) , Shokuyi (1976) , Mansourian and Ayatollahi (1977) and most importantly, the group Bethel and Sektop group.

After the revolution, studies of this sector continued by Nabati (1978), Shokuyi (1986), Parviz Piran (1987), Zahid Zahedani (1990), Hosseinzadeh Dalir (1992), Ahmadian (1992) and Hatami Nejad and Zomorodian (1993), Kargar and Sarvar (2011).

\section{Research Methodology}

The population of this research included the marginalized households of Sheikh Jafar Qorveh in 2013 containing 97 households. The volume of the sample was estimated 78 households using Cochran (1977) as below which were selected by the sample random sampling.

$$
n=\frac{\frac{t^{r} p q}{d^{r}}}{1+\frac{1}{N}\left(\frac{t^{r} p q}{d^{r}}-1\right)}=\frac{\frac{1 / 97^{r} \times \cdot / 0 x \cdot 10}{1 / 00^{r}}}{1+\frac{1}{q v}\left(\frac{1 / 97^{r} \times \cdot / 0 x \cdot 10}{1 \cdot 1 \cdot 0^{r}}-1\right)}=v \Lambda
$$

In order to collect data, a research-made questionnaire was used. This questionnaire contained 21 items which were sorted as a five-point Likert Scale from very low to very high and respectively 1 to 5 scores. This questionnaire studies three economic, social and cultural factors and it generally evaluates the marginalization factors. The validity of the questionnaire was approved by professors and experts. Moreover, the reliability coefficient of the questionnaire was calculated by using Cronbach alpha which was 772/0, $732 / 0$ and $748 / 0$ for the economic factors, the social factors and the cultural factors, respectively. Such value is acceptable for a research work according to Nanaly Table (1978).

In this research, table of frequency distribution and percentage, the central and distribution indexes and one-sample analytical t-test and Friedman were utilized. However, before conducting the mentioned tests, the outliers and final values were eliminated and studied. Then, the assumptions of parametric statistical tests were studied using Kolmogorov-Smirnov test to check the normality of the data distribution. The data analysis was performed using SPSS software.

\section{Results}

In this part, frequency distribution of the sample group is represented, based on variables of demography, descriptive indexes of the marginalization factors, as well as the economic, social and cultural factors, respectively.

Table 1 indicates that $2 / 87 \%$ of the sample group consisted of male marginalization dwellers and the rest of $8 / 12 \%$ were female. The largest age group in the sample were people of 41 50 years old. Also 5/88\% of the sample group had no diploma degree, the rest had diploma and $41 \%$ of them were workers.

The correlation coefficient results of Pearson show that there is a significant relation between social and economic factors $(\mathrm{P}<358 / 0=r, 01 / 0)$, cultural and economic factors $(\mathrm{P}<425 / 0=r, 05 / 0)$, cultural and social factors $(\mathrm{P}<302 / 0=\mathrm{r}, 001 / 0)$. 
Table 1. Frequency distribution of the sampling group based on the variables of Demography

\begin{tabular}{ccc}
\hline Level Variable & F & P \\
\hline Gender & 10 & $12 / 8$ \\
Female & 68 & $87 / 2$ \\
Male & & \\
Age group & 7 & 9 \\
$21-30$ & 16 & $20 / 5$ \\
$31-40$ & 23 & $29 / 5$ \\
$41-50$ & 18 & $23 / 1$ \\
$51-60$ & 9 & $11 / 5$ \\
$61-70$ & 5 & $6 / 4$ \\
$71-80$ & & \\
Degree & 69 & $88 / 5$ \\
Under diploma & 9 & $11 / 5$ \\
Diploma & & \\
Employment Status & 32 & 41 \\
Worker & 15 & $19 / 2$ \\
Farmer & 11 & $14 / 1$ \\
Tradesman & 6 & $12 / 8$ \\
Unemployed & 10 & $5 / 1$ \\
Housekeeper & 4 &
\end{tabular}

Table 2. Inner correlation matrix of the marginalization factors

\begin{tabular}{cccc}
\hline Components of marginalization & $\begin{array}{c}\text { Economic } \\
\text { factor }\end{array}$ & Social factor & Cultural factor \\
\hline Economic Factor & 1 & & \\
Social factor & $0 / 358$ & 1 & \\
Cultural factor & $0 / 001^{* *}$ & & 1 \\
& $0 / 425$ & $0 / 302$ & \\
\hline
\end{tabular}

** $\mathrm{P}<0 / 01, \mathrm{n}=78$

Table 3. Evaluation of the sample's group view about role of the economic factors in marginalization

\begin{tabular}{cccccc}
\hline Variable & The viewed average & Scale mean & $\mathbf{t}$ & $\mathbf{d f}$ & $\mathbf{P}$ \\
$\begin{array}{c}\text { Economic } \\
\text { factor }\end{array}$ & $34 / 81$ & 30 & $6 / 150$ & 77 & $0 / 0001^{* *}$ \\
\hline
\end{tabular}

** $\mathrm{P}<0 / 01, \mathrm{n}=78$

In order to test the first hypothesis of the research, the results of one-sample t-test shows there is a significant difference between population of the sampling group and scale mean in terms of economic factors in the marginalization.

$$
\left(t_{(77)}=6 / 105, P<0 / 01\right)
$$

Therefore, the view average of the sampling group will be more than the scale mean. Thus, the first hypothesis is approved and it is possible to mention that 
the economic factors are effective in the

marginalization.

Table 4. Distribution of the sample group to items of the role of economic factors in marginalization

\begin{tabular}{|c|c|c|c|}
\hline Row & Obstacle & Rating average & Rate \\
\hline 1 & $\begin{array}{l}\text { Access to better job at the present location has } \\
\text { effect on the cities' marginalization. }\end{array}$ & 6.71 & 1 \\
\hline 2 & $\begin{array}{l}\text { Low income of families in the previous location } \\
\text { can lead to the cities' marginalization. }\end{array}$ & 6.69 & 2 \\
\hline 3 & $\begin{array}{l}\text { Unemployment in the previous location can lead } \\
\text { to the cities' marginalization. }\end{array}$ & 6.53 & 3 \\
\hline 4 & $\begin{array}{l}\text { Lack of suitable job in the previous location can } \\
\text { lead to the cities' marginalization }\end{array}$ & 6.20 & 4 \\
\hline 5 & $\begin{array}{l}\text { To achieve more income at the present location } \\
\text { has effect on the cities' marginalization. }\end{array}$ & 5.74 & 5 \\
\hline 6 & $\begin{array}{l}\text { Value of land and house at the present location } \\
\text { has effect on the cities' marginalization. }\end{array}$ & 5.60 & 6 \\
\hline 7 & $\begin{array}{l}\text { Closeness to workplace at the present location } \\
\text { has effect on the cities' marginalization. }\end{array}$ & 5.39 & 7 \\
\hline 8 & $\begin{array}{l}\text { Lack of access to the suitable communicative } \\
\text { paths at the previous location has effect on } \\
\text { cities' marginalization. }\end{array}$ & 4.90 & 8 \\
\hline 9 & $\begin{array}{l}\text { Reduction of financial resources and lack of } \\
\text { attention to agricultural sector at the previous } \\
\text { location has effect on cities' marginalization. }\end{array}$ & 4.17 & 9 \\
\hline 10 & $\begin{array}{l}\text { Agricultural mechanism at the previous location } \\
\text { has effect on cities' marginalization. }\end{array}$ & 10.3 & 10 \\
\hline
\end{tabular}

In order to answer the first question of the research, the results of the Friedman test shows there is a significant difference between the rating average of the economic factors according to the view of the sample group members $\mathrm{P}<0 / 01 \quad X^{2}(32)$ $=126 / 818$. Moreover, access to a better job at the current location by rating average of $6 / 71$ has been stated as the most economic factors in marginalization and agricultural mechanism at the previous location by rating average of $10 / 3$ has been stated as the least economic factors in marginalization.

Table 5. Evaluation of the sample group perspective about the role of social factors in marginalization

\begin{tabular}{cccccc}
\hline $\begin{array}{c}\text { Variable } \\
\begin{array}{c}\text { Economic } \\
\text { factor }\end{array}\end{array}$ & The viewed average & Scale mean & $\mathbf{T}$ & $\mathbf{d f}$ & $\mathbf{P}$ \\
\hline
\end{tabular}

${ }^{* *} \mathrm{P}<0 / 01, \mathrm{n}=78$

In order to test the second hypothesis of the research, the results of one-sample $t$ test shows there is a significant difference between population of the sampling group and scale mean in terms of social factors in the marginalization.

$$
\left.t_{(77)}=6 / 105, P<0 / 01\right)
$$


Therefore, the view average of the sampling group will be less than the scale mean. Thus, the second hypothesis is approved and it is possible to mention that the social factors are effective in the marginalization.

Table 6. Average rating of responses of the sampling group to items of social factor role in marginalization

\begin{tabular}{|c|c|c|c|}
\hline Row & Obstacle & Rating obstacle & Rate \\
\hline 1 & $\begin{array}{c}\text { Lack of access to amenities at the previous location } \\
\text { has effect on marginalization of cities. }\end{array}$ & 4.64 & 1 \\
\hline 2 & $\begin{array}{c}\text { Lack of development and progress possibility at } \\
\text { the previous location has effect on marginalization } \\
\text { of cities. }\end{array}$ & 4.53 & 2 \\
\hline 3 & $\begin{array}{l}\text { Low job and life value at the previous location has } \\
\text { effect on marginalization of cities. }\end{array}$ & 4.47 & 3 \\
\hline 4 & $\begin{array}{l}\text { Distance from relatives and acquaintances at the } \\
\text { previous location has effect on marginalization of } \\
\text { cities. }\end{array}$ & 2.74 & 4 \\
\hline 5 & $\begin{array}{l}\text { Lack of proper marriage requirement at the } \\
\text { previous location has effect on marginalization of } \\
\text { cities. }\end{array}$ & 2.37 & 5 \\
\hline 6 & $\begin{array}{l}\text { Discrepancy and ethnic conflicts at the previous } \\
\text { location has effect on marginalization of cities. }\end{array}$ & 2.26 & 6 \\
\hline
\end{tabular}

In order to answer the second question of the research, the results of the Friedman test show there is a significant difference between the rating average of the social factors according to the view of the sample group members $\mathrm{P}<0 / 01 \mathrm{X}^{2}(5)=176 / 532$. Moreover, access to welfare facilities at the previous location by rating average of $4 / 64$ has been stated as the most social factors in marginalization and discrepancy and ethnic conflicts at the previous location by rating average of $2 / 26$ as the least social factors in marginalization.

In order to test the third hypothesis of the research, the results of one-sample t-test show there is a significant difference between population of the sampling group and scale mean in terms of cultural factors in the marginalization.

$$
\left(t_{(n)}=8.260, P<0 / 01\right)
$$

Table 7. Average rating of view of the sampling group about role of cultural factors in marginalization

\begin{tabular}{cccccc}
\hline Variable & The viewed average & Scale mean & $\mathbf{t}$ & $\mathbf{d f}$ & $\mathbf{P}$ \\
Economic factor & $18 / 85$ & 15 & $8 / 260$ & 77 & $0 / 0001^{* *}$ \\
\hline $\mathrm{P}<0 / 01, \mathrm{n}=78$ & & & & &
\end{tabular}

Table 8. Average rating of the answers of the sampling group's members to the items of social factors' role in marginalization

\begin{tabular}{cccc}
\hline Row & Obstacle & Rating Average & Rate \\
\hline 1 & $\begin{array}{c}\text { Access to amenities at the current location has effect } \\
\text { on marginalization of cities. }\end{array}$ & 3.53 & 1
\end{tabular}




\begin{tabular}{cccc}
\hline 2 & $\begin{array}{c}\text { Lack of access to educative facilities at the previous } \\
\text { location has effect on marginalization of cities. } \\
\text { Access to educative facilities at the current location } \\
\text { has effect on marginalization of cities. }\end{array}$ & 3.37 & 3.22 \\
4 & $\begin{array}{c}\text { Poor cultural communications at the previous } \\
\text { location has effect on marginalization of cities. } \\
\text { Lack of suitable requirement to grow characteristics } \\
\text { at the previous location has effect on marginalization } \\
\text { of cities. }\end{array}$ & 2.50 & 5 \\
\hline
\end{tabular}

$\mathrm{n}=78, \chi^{2}=47 / 880, \mathrm{df}=4,{ }^{* *} \mathrm{P}<0 / 01$

Therefore, the view average of the sampling group will be more than the scale mean. Thus, the third hypothesis is approved and it is possible to mention that the cultural factors are not effective in the marginalization.

In order to answer the third question of the research, the results of the Friedman test show there is a significant difference between the rating average of the cultural factors according to the view of the sample group members $\mathrm{P}<0 / 01 \quad X^{2}(4)=47 / 880$. Moreover, access to welfare facilities at the current location by rating average of 3/53 has been stated as the most cultural factors in marginalization and lack of suitable requirements to grown people's characteristics at the previous location by rating average of $2 / 39$ as the least cultural factors in marginalization.

Table 9. Average rating of the answers of the sampling groups' members about role of economic, social and cultural factors in marginalization

\begin{tabular}{cccccc}
\hline Variable & Viewed Average & Scale Average & $\mathrm{t}$ & $\mathrm{df}$ & $\mathrm{P}$ \\
Marginalization Factors & $69 / 70$ & 63 & $915 / 5$ & 77 & $* * 0001 / 0$ \\
\hline
\end{tabular}

** $\mathrm{P}<0 / 01, \mathrm{n}=78$

In order to test the general hypothesis of the research, the results of one-sample $t$ test shows there is a significant difference between population of the sampling group and scale mean in terms of social, economic and cultural factors in the marginalization.

$\left(\mathrm{t}_{(77)}=51915, \mathrm{P}<0 / 01\right)$

Therefore, the view average of the sampling group will be more than the scale mean. Thus, the general hypothesis is approved and it is possible to mention that the social, economic and cultural factors are effective in the marginalization.

In response to the first research hypothesis, the results of one sample t-test indicate there is no significant difference between average economic factor of the sample group and theoretical average. So the average of the economic factors of the sample group was higher than that of the theoretical scale mean. These results are partly consistent with the results of Castells (1977), Nelson (1988), Elias (1966), Klynard (1966), Touli (1989) also Haji Yousefi (1972), Hedayati and Mansuri (1978), Mansourian and Ayatollahi (1978), Dehghan (1989), Ahmadian (11991), Latif (1993), Afrough (1998), Sheybak (2004), Khubayand (2005), Rousta and Palizban (2000) Meshkini Parhiz and Tafakori Dobakhshari (2000), Zangi Abadi and Mobaraki (2012).

Piran (2002). 


\section{Recommendations}

\section{Practical Recommendations}

The recommendations of organization and status improvement in marginalization of Qorveh (Sheikh Jafar quarter) have been categorized in 4 sections as study and understanding, prevention, treatment and continuous care in terms of the strategic views.

\section{A) City study and understanding:} the first condition to find a cure for pains is to understand them well. One of the managerial steps is to understand the city in its true sense. City is a complex system in terms of the rural system and the system's problems should be sought in the system itself. There are recommendations in this matter.

1) The urban planning pioneer to urbanism should be in a way that it would meet all needs and interests. For example, if there are 3 people with 3 different financial conditions, there should be 3 options for construction in order to allow the people to have appropriate selections. An example of such an idea can be observed in Turkey.

2) The experiences of the previous managers in dealing with marginalization phenomenon should be used, that is, we shouldn't decide to invent the wheel again.

B) Prevention: Prevention is more important than treatment and it is recommended that we take the following measures to prevent unauthorized constructions:

1- Necessity to apply coordinated regulations and guidelines for all the population centers and activities in Qorveh's sanctum and providing sanctum projects based on frameworks of comprehensive project of Qorveh along with construction regulations

2- Serious and comprehensive reaction without tolerance along with administrative authority (authority is a power resulting from interaction, charisma, capacity building and empowerment) with any infringement in construction in the Qorveh's limits

3- Urban management is done as good urban warrant validity: spontaneous presence of municipality and heads of departments in legal areas and urban sanctum can lead to serious management conflicts in guiding and directing all urban physical changes.

4- Providing requirements and encouraging the private sector in distribution of low-price housing in the rural areas and awarding relevant loans along with running their insurances due to risk reduction of lack of capital return which is a method used in UK.

5- Job Creation for the villagers, especially in the manufacturing sectors in order to reduce unemployment and poverty and to improve their life quality and to promote social and economic justice for all groups in the village level.

6- Development and construction of health care centers for family planning and improvement of educational facilities in deprived villages of Qorveh.

7- $\quad$ Targeted housing programs and more support of government in agricultural sector and farmers and ranchers in deprived villages of Qorveh in comparison with the past

8- Marking and identifying the specific sanctum within the city according to the map on the ground

9- Reinforcing the power structure (Islamic Councils) in the villages

C) Treatment and proposals for the current status of marginalized area of Sheikh Jafar

1- Planning and enabling informal settlements

2- Social, cultural, long-term, short-term planning by authorities and relevant 
planners in order to promote culture of people living in marginalized areas and to attract their participation in urban system and formation of NGO organization, social and people institutions in slum area of Sheikh Jafar Qorveh.

\section{Refrences}

Etemad, G. (1998). Urbanization in Iran. Tehran: Agah Publication.

Haji- Yousefi, A. (2003). Marginal urban phenomenon before the revolution, settlement in marginalization informal settlements. Tehran: University of Welfare and Rehabilitation Sciences.

Strategic Planning of Urban Development (recent global experience and its position in Iran), Tehran: Bureau of Architecture and Urban Design of Ministry of Roads and Urban Development.

Rabbani, R. et al., (2009). Evaluation of effective factors on shaping marginalization and its social consequences in Ahwaz. Journal of Geography and Development, fourth year.

Rezai, S. (1995). city and urban developments in Kermanshah with a focus on marginalization. Master thesis.

Sarvar, R. (2011). Civil rights, academic University pamphlet, Science and Research Branch, Islamic Azad University, Tehran.

Saeednya A. (2000). Urban centers system - residential areas. Municipalities Guide Green Book, Volume 4. Centre Ministry of Urban Planning.

Shokuyi, H. (2000). New ideas in philosophy of geography, Tehran: Botanic publication.

Kargar B. and Sarvar, R. (2011). City, margins and Social Security (with emphasis on the southern edge of the urban area of Tehran and Islam Shahr). Tehran: publication of Armed Forces Geographical Organisation.

Jihad, M. (1987). Definition and concept of marginalization and extending it in the world. Jihad magazine, No. 104.

Statistical Center of Iran. 2011. Detailed results of the General Census of Population and Housing Qorveh city.

Boom Negar Pars Consulting Engineers. (2010). Regulations of detailed project of Qorveh.

Naghdi A. and Sadeghi, R. (2006). Journal of Social Welfare. Fifth year. No. 20.

Athari, K. (2005). Marginalization in cities and effects and its consequences

Castells, M. (1977), The urban question, London.

Lapoutre, D. (2001). Coeur de Banlieue, Paris: Odile, Jacobe.

Mumtaz B. (2001), Why cities need slums.

Park, Robert E. (1937). Human migration and marginal man, Amrican Journal, of sociology.Vol. 33.

Ray, Alain (1994). «Vousavezdit Banlieue? » Le Débat, n. 8.

UN-HABITAT920050. Slums of the world:the face of urban poverty in the new millennium.

http://fa.wikipedia.org

http://www. unhabitat.org

http://www.cityofkaraj.com

http://www.nasour.net 
How to cite this article: Ata Olah Erfani, Masoud Almasi, Hamideh Reshadatjoo, Evaluation of the Relevant Factors with the Formation of Marginalization in Qorveh, a Case Study in Sheikh Jafar Quarter. International Journal of Advanced Studies in Humanities and Social Science, 2019, 8(3), 241-254. http://www.ijashss.com/article_84371.html 